Asian J. Med. Biol. Res. 2019, 5 (2), 94-99; doi: 10.3329/ajmbr.v5i2.42490

\author{
Asian Journal of \\ Medical and Biological Research \\ ISSN 2411-4472 (Print) 2412-5571 (Online) \\ www.ebupress.com/journal/ajmbr
}

\title{
Review \\ The influence of traditional Iranian and Chinese medicine on western and islamic countries
}

\author{
Mohamad Hesam Shahrajabian ${ }^{1,2}$, Wenli Sun ${ }^{1,2}$ and Qi Cheng ${ }^{1,2^{*}}$ \\ ${ }^{1}$ Biotechnology Research Institute, Chinese Academy of Agricultural Sciences, Beijing 100081, China \\ ${ }^{2}$ Nitrogen Fixation Laboratory, Qi Institute, Building C4, No.555 Chuangye Road, Jiaxing 314000, Zhejiang, \\ China
}

*Corresponding author: Qi Cheng, Biotechnology Research Institute, Chinese Academy of Agricultural Sciences, Beijing 100081, China. E-mail: chengqi@ caas.cn

Received: 07 June 2019/Accepted: 29 June 2019/ Published: 30 June 2019

\begin{abstract}
Traditional Chinese and Iranian medicine are ancient medical and health care systems that still forms an important part of diagnosis and treatment systems in Iran, China and other parts of the world. The integration of these two systems and modern biomedicine is also an important issue. Iranian and Chinese traditional medicines recommended for health promotion and well-being. Chinese herbal drugs have been described by medieval Muslim medical scholars such as Tabari, Rhazes, Haly Abbas, Avicenna and Jurjani (1137 CE). Traditional Chinese and Iranian medicine play an important role in sustainable agriculture and food systems, it also offers a holistic approach to prevent diseases while making appropriate use of organic and herbal products especially growth by small-scale family farmers. Both Iranian and Chinese traditional medicines may help to balance temperature, and both can be health prevention and preservation. Traditional healing practices consist of Islamic religious text based practices, Islamic worship practices and folk healing practices, Islamic religious text based practices are included spiritual healing, medicinal herbs, applied therapy and dietary prescriptions. At present, herbal medications or related products in the global market are derived from Chinese herbs, Indian herbs, Iranian herbs, Arabic herbs, and Western herbs. Herbal remedies may also be classified into three categories, namely, modern herbs, theoretical herbs, and empirical herbs, in accordance with their nature/characteristics and the nature of current usage. Traditional Chinese and Iranian medicines are inexpensive and available to all and they also focus more on fitness than illness
\end{abstract}

Keywords: traditional Iranian medicine; traditional Chinese medicine; islamic countries; pharmaceutical science

\section{Introduction}

Most population of the world, especially in developing countries relies on traditional medicine (Soleymani et al., 2010; Shahrajabian et al., 2011; Soleymani et al., 2013; Yong and Shahrajabian, 2017; Shahrajabian et al., 2018; Soleymani and Shahrajabian, 2018; Ogbaji et al., 2018; Yong et al., 2018; Shahrajabian et al., 2019a,b). Iranian traditional medicine is one of the most famous and ancient forms of traditional medicine, whose earliest record can be traced back to 6,500 BC (Shojaii et al., 2016; Zeinalian et al., 2017). It is believed that traditional Chinese medicine (TCM) has a 3000-4000- year history, and TCM spread across Asia throughout the centuries (Shahrajabian et al., 2019c,d,e). TCM is the overreaching umbrella for many disciplines, and throughout history, TCM and acupuncture have been subjected to religious, cultural and political pressures (Ogbaji et al., 2013; Shahrajabian et al., 2019f,g,h,i). Archeological studies have shown that the practice of herbal medicine dates as far back as 60,000 years ago in Iraq and 8,000 years ago in China (Leroi Gourhan, 1975). Traditional Chinese medicine included 5 branches, namely, acupuncture and Moxibustion, Chinese herbology (commonly known as Chinese herbal medicine), Qigong healing, Tuina therapeutic massage, and Chinese dietary therapy 
( $\mathrm{Lu}$ and Lu, 2014). During the Islamic Golden Age, Persian physicians contributed to medicine in two phases. The philosophers, Gerber, Al-kindi, Rhazes, Al-Farabi, Avicenna, and Averroes had profound effect on the Dark Ages of Europe (Petri et al., 2015). Chinese herbal drugs have been described by medieval Muslim medical scholars such as Tabari (870 CE), Rhazes (925 CE), Haly Abbas (982 CE), Avicenna (1037 CE) and Jurjani (1137 CE). The term al-sin (the Arabic word for China) is used 46 times in Avicenna's Canon of Medicine in reference to herbal drugs imported from China. Cinnamon (dar sini; "Chinese herb"), wild ginger (asaron), rhubarb (rivand-e sini), nutmeg (basbasa), incense tree wood (ood), cubeb (kababe) and sandalwood (sandal) were the most frequently mentioned Chinese herbs in Islamic medical books. There are also multiple similarities between the clinical uses of these herbs in both medical systems. Different traditional medicines are consisted of Chinese, Persian, Graeco-Roman and Ayurvedic theories and practices (Soleymani et al., 2011a; Soleymani et al., 2011b; Soleymani and Shahrajabian, 2012a; Soleymani and Shahrajabian, 2012b; Soleymani et al., 2016; Soleymani et al., 2017). Similar to the Graeco-Arabic medicine, the Iranian traditional medicine is based on the theory that the human body is filled with four basic substances, called humors, including Phlegm (Balgham), Blood (Dam), Yellow bile (Șafra) and Black bile (Sauda). The four substances determine the physical and mental characteristics of each person, also known as mizaj or temperaments. The main essence of the Iranian traditional medicine in maintaining health and treating illnesses is that each person should choose a life style which matches their distinguished mizaj. Mijaj and genetics are relatively similar as the temperament will be determined once an embryo starts to develop. Furthermore, the dominant mizaj can be inheried from the parents. Traditional Chinese medicine plays an important role in sustainable agriculture and food systems, it also offers a holistic approach to prevent diseases while making appropriate use of organic and herbal products especially growth by small-scale family farmers. In the early 11th century, Avicenna (980-1037), a great philosopher and physician, incorporated a number of Chinese herbal preparations in his book Pharmacopoeia. Heydari et al. (2015) reported that Chinese herbal drugs were a major component of the exchange of goods and knowledge between China and the Islamic and later to the western world amid this era. The life style rules in Iranian traditional medicine are mainly focused on six core principles, including food and drinks, climatic conditions and environment, sleeping and waking, physical activities, psychiatric conditions and ridding body from waste materials such as sweat, urine or feces. Zeinalian et al. (2015) showed that Iranian-Islamic traditional medicine (IITM) offers an ancient comprehensive personalized medicine (PM) which is more available and inexpensive compared to the modern PM, and it may focus more on fitness than illness in comparison. The most important similarities and differences between four main medical systems is shown in Table 1. Chinese herbal medicine (CHM) in China is presented in Figure 1. Achievements of Arabic medicine and pharmacy is presented in Figure 2. A unifying conceptual model of traditional Arabic and Islamic medicine is shown in Figure 3.

Table 1. The most important similarities and differences between four main medical systems (Al-Rawi and Fetters, 2012).

\begin{tabular}{|c|c|c|c|c|}
\hline Criteria & Ayurvedic medicine & Traditional Chinese medicine & $\begin{array}{l}\text { Greek } \\
\text { medicine }\end{array}$ & $\begin{array}{l}\text { Islamic } \\
\text { medicine }\end{array}$ \\
\hline $\begin{array}{l}\text { Inherent } \\
\text { wisdom } \\
\text { responsible for } \\
\text { health } \\
\text { restoration and } \\
\text { preservation }\end{array}$ & Prana & Chi Energy & $\begin{array}{l}\text { Physis } \\
\text { (healing } \\
\text { power of } \\
\text { nature) }\end{array}$ & $\begin{array}{l}\text { Physis (healing } \\
\text { power of nature) }\end{array}$ \\
\hline $\begin{array}{l}\text { Active force } \\
\text { that maintains } \\
\text { equilibrium }\end{array}$ & $\begin{array}{l}\text { Doshas (energy } \\
\text { dominance) }\end{array}$ & Yin and Yang (energy dominance) & $\begin{array}{l}\text { Humours } \\
\text { (metabolic } \\
\text { dominance) }\end{array}$ & $\begin{array}{l}\text { Humours and } \\
\text { Tempermental } \\
\text { imbalance }\end{array}$ \\
\hline $\begin{array}{l}\text { Spiritual } \\
\text { Influence }\end{array}$ & Hinduism/Buddhism & Taoism/Confuciansim/Buddism & $\begin{array}{l}\text { Abrahamic } \\
\text { scriptures }\end{array}$ & $\begin{array}{l}\text { Abrahamic } \\
\text { scriptures }\end{array}$ \\
\hline
\end{tabular}




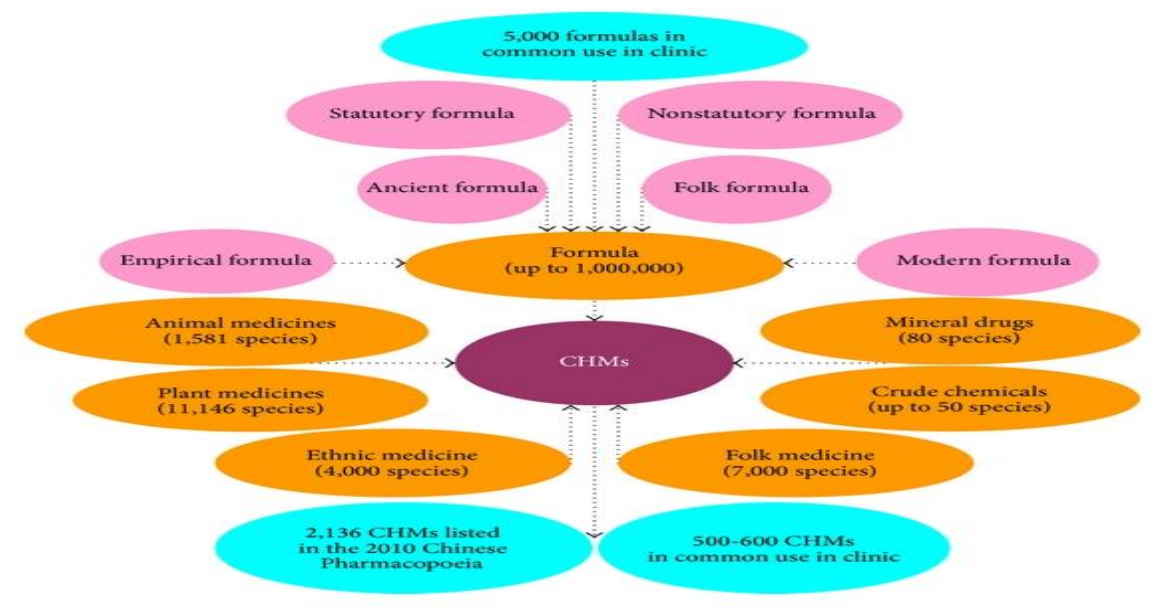

Figure 1. Chinese herbal medicine (CHM) in China (Pan et al., 2014).

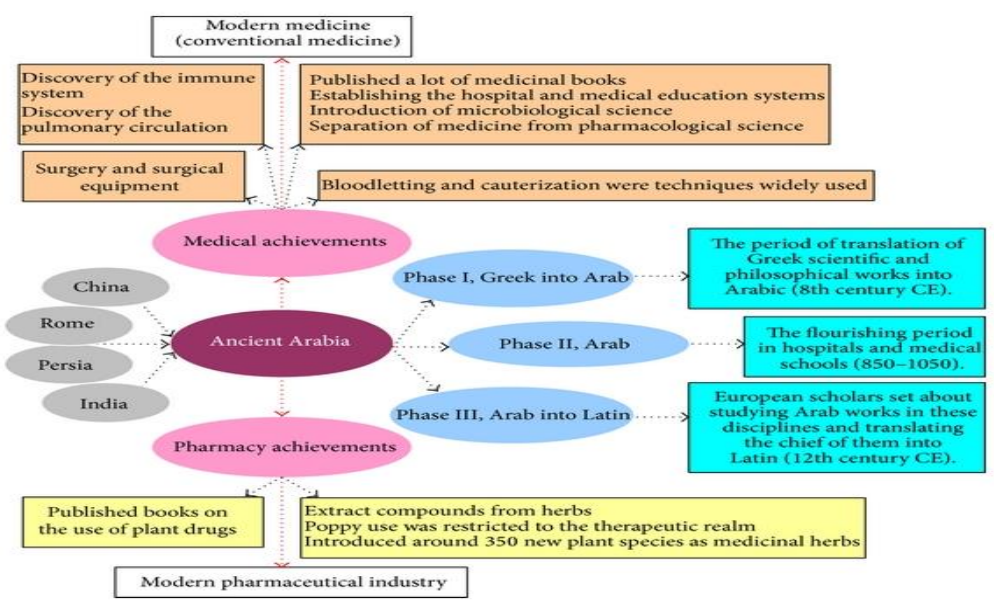

Figure 2. Achievements of Arabic medicine and pharmacy (Pan et al., 2014).

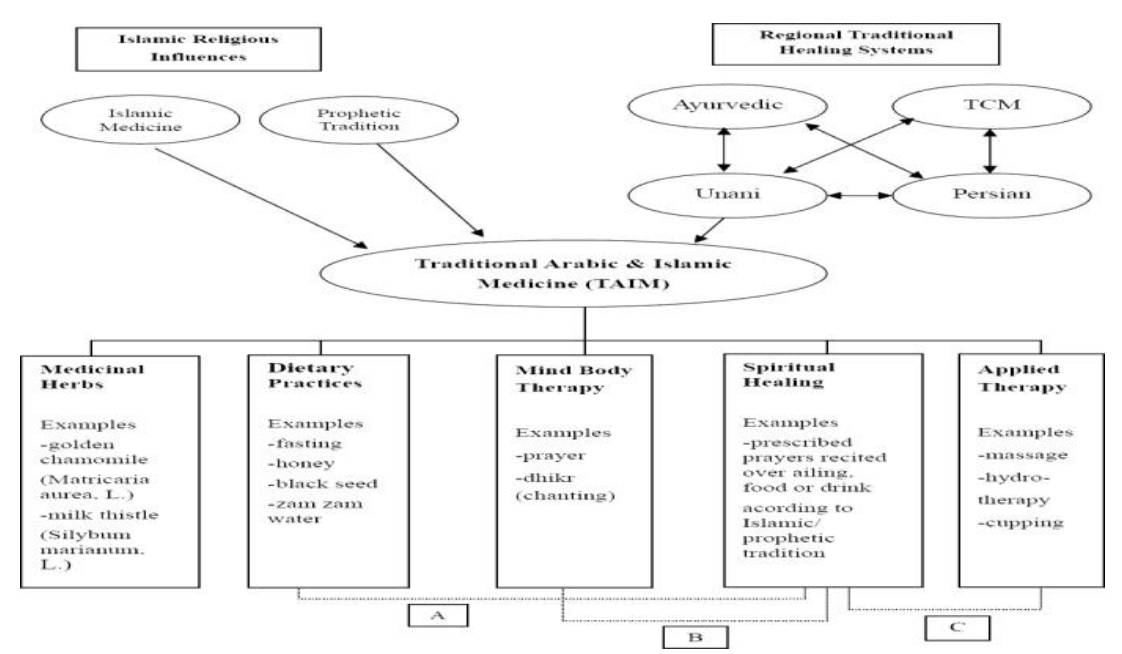

Figure 3. A unifying conceptual model of traditional Arabic and Islamic medicine (Al-Rawi and Fetters, 2012). 
Traditional healing practices consist of Islamic religious text based practices, Islamic worship practices and folk healing practices, Islamic religious text based practices are included spiritual healing, medicinal herbs, applied therapy and dietary prescriptions. Folk healing practices is included medicinal herbs and applied therapy. Sarebanha et al. (2016) concluded that the methods of western medicine diagnosis with science and technology (Western diagnostic techniques) can be introduced to Chinese and Iranian clinical practice, which can improve the accuracy of Chinese and Iranian diagnosis and lead to an advantage for improving the medical efficiency in the clinical treatment. Rezaeizadeh et al. (2009) reported that traditional medicine has the advantage of being considered as part of the culture therefore, bypassing cultural issues that may affect the practice of medicine, and it can be used in conjunction with and as an aid to the conventional medicine. Comparisons of methods of diagnosis in traditional Iranian and Chinese medicine is shown in Table 2.

Table 2. Comparisons of methods of diagnosis in traditional Iranian medicine and traditional Chinese medicine (Sarebanha et al., 2016).

\begin{tabular}{|c|c|}
\hline Method of diagnosis in traditional Iranian medicine & Method of diagnosis in traditional Chinese medicine \\
\hline Inspection & Inspection \\
\hline Palpation & Listening and Smelling \\
\hline Percussion & Interrogation \\
\hline Interrogation (Questioning) & Pulse examination, Palpation \\
\hline \multicolumn{2}{|l|}{ Smelling } \\
\hline \multicolumn{2}{|l|}{ Urine Analysis } \\
\hline Characteristic of traditional Iranian medicine & Characteristics of traditional Chinese medicine \\
\hline Temperaments: & Pulse taking \\
\hline Warm and Wet & Tongue observation \\
\hline \multicolumn{2}{|l|}{ Warm and Dry } \\
\hline \multicolumn{2}{|l|}{ Cold and Dry } \\
\hline \multicolumn{2}{|l|}{ Cold and Wet } \\
\hline \multicolumn{2}{|l|}{ Humors: } \\
\hline \multicolumn{2}{|l|}{ Blood } \\
\hline \multicolumn{2}{|l|}{ Bile } \\
\hline \multicolumn{2}{|l|}{ Black bile } \\
\hline \multicolumn{2}{|l|}{ Phlegm } \\
\hline \multicolumn{2}{|l|}{ Urine analysis } \\
\hline Pulse taking & \\
\hline
\end{tabular}

\section{Conclusions}

Integrative use of modern agriculture and science of traditional Chinese and Iranian herbs with novel technologies especially in Islamic countries will secure production of medicinal herbs in different parts of the world. Despite the scarcity of medical knowledge in the Koran, Arabs adopted the ancient medical practices that originated from Mesopotamia, Greece, Rome, Persia, India and China. Traditional healing practices consist of Islamic religious text based practices, Islamic worship practices and folk healing practices, Islamic religious text based practices are included spiritual healing, medicinal herbs, applied therapy and dietary prescriptions. At present, herbal medications or related products in the global market are derived from Chinese herbs, Indian herbs, Iranian herbs, Arabic herbs, and Western herbs. Herbal remedies may also be classified into three categories, namely, modern herbs, theoretical herbs, and empirical herbs, in accordance with their nature/characteristics and the nature of current usage. There is no doubt that herbal products will continue to play a crucial role in the health care system of human societies, not to mention that secondary metabolites of plants are economically important as drugs, fragrances, pigments, food additives, and pesticides. Given the growing popularity of the Iranian and Chinese traditional medicine among the public, many scholars and scientists express optimism that continued research in the field will lead to further revival of the scientific method and bring about more breakthroughs in the medical science in general. The comprehensive Iranian and Chinese traditional medicine cover all aspects of health and disease, including both spiritual and physical features. Besides, traditional Chinese and Iranian medicines are inexpensive and available to all and they also focus more on fitness than illness. 
Conflict of interest

None to declare.

\section{References}

Al-Rawi S and MD Fetters, 2012. Traditional Arabic and Islamic medicine: a conceptual model for clinicians and researchers. Glob. J. Health Sci., 4: 164-179.

Heydari M, MH Hashempur, MH Ayati, D Quintern, M Nimrouzi, and SH Mosavat, 2015. The use of Chinese herbal drugs in Islamic medicine. J. Integr. Med., 13(6). DOI: 10.1016/S2095-4964(15)60205-9

Leroi Gourhan A, 1975. The flowers found with Shanidar IV, a Neanderthal burial in Iraq. Science, 190: 562564.

Lu WI and DP Lu, 2014. Impact of Chinese herbal medicine on American society and health care system: perspective and concern. Evidence-Based Complementary and Alternative Medicine, Article ID 251891, 6 pages.

Ogbaji PO, MH Shahrajabian and X Xue, 2013. Changes in germination and primarily growth of three cultivars of tomato under diatomite and soil materials in auto-irrigation system. Int. J. Biol., 5: 80.

Ogbaji PO, J Li, X Xue, MH Shahrajabian and EA Egrinya, 2018. Impact of bio-fertilizer or nutrient solution on Spinach (Spinacea Oleracea) growth and yield in some province soils of P.R. China. Cercetari Agronomice in Moldova, 2: 43-52.

Pan SY, G Litscher, SH Gao, SF Zhou, ZL Yu, HQ Chen, SF Zhang, MK Tang, JN Sun and KM Ko, 2014. Historical perspective of traditional indigenous medical practices: the current renaissance and conservation of herbal resources. Evidence-Based Complementary and Alternative Medicine. Article ID 525340, 20 pages.

Petri RP, Md Faapmr, Faaim and C Mc, 2015. Historical and cultural perspectives on integrative medicine. Med. Acupunct., 27: 309- 317.

Rezaeizadeh H, M Alizadeh, M Naseri and MR Sham Ardakani, 2009. The traditional Iranian medicine point of view on health and disease. Iran. J. Public Health, 38: 169-172.

Sarebanha S, AH Kazemi, P Sadrolsadat and N Xin, 2016. Comparison of traditional Chinese medicine and traditional Iranian medicine in diagnostic aspect. Traditional and Integrative Medicine, 1: 75-78.

Shahrajabian MH, A Soleymani and L Naranjani, 2011. Grain yield and forage characteristics of forage sorghum under different plant densities and nitrogen levels in second cropping after barley in Isfahan, Iran. Research on Crops, 12: 68-78.

Shahrajabian MH, W Sun and Q Cheng, 2018. A review of goji berry (Lycium barbarum) in traditional Chinese medicine as a promising organic superfood and superfruit in modern industry. Academia Journal of Medicinal Plants, 6: 437-445.

Shahrajabian MH, W Sun and Q Cheng, 2019a. Astragalus, an ancient medicinal root in traditional Chinese medicine, a gift from silk road. International Journal of Agriculture and Biological Sciences, 3: 27-38.

Shahrajabian MH, M Khoshkharam, W Sun and Q Cheng, 2019b. Exploring responses of Berseem clover cultivars in low input cultivation management for agricultural sustainability. World Scientific News, 131: 197-206.

Shahrajabian MH, M Khoshkharam, W Sun and Q Cheng, 2019c. The effect of pretreatment factors on seed germination and seedling growth of anise (Pimpinella anisum L.). Middle East J. Sci., 5: 86-93.

Shahrajabian MH, W Sun and Q Cheng, 2019d. Eternal life by traditional Chinese medicine and herbs, treasures of Asia via one belt and one road. Book Publisher International. 22 pages.

Shahrajabian MH, W Sun and Q Cheng, 2019e. A review of ginseng species in different regions as a multipurpose herb in traditional Chinese medicine, modern herbology and pharmacological science. J. Med. Plants Res., 13: 213-226.

Shahrajabian MH, M Khoshkharam, W Sun and Q Cheng, 2019f. Germination and seedlings growth of corn (Zea mays L.) to allelopathic effects of rice (Oryza sativa L.). Trop. Plant Res., 6: 152-156.

Shahrajabian MH, W Sun and Q Cheng, 2019g. Traditional Chinese medicine and agriculture; organic life and sustainability for future. GSC Biological and Pharmaceutical Sciences, 7: 91-95.

Shahrajabian MH, W Sun and Q Cheng, 2019h. Clinical aspects and health benefits of ginger (Zingiber officinale) in both traditional Chinese medicine and modern industry. Acta Agriculturae Scandinavica, Section B-Soil \& Plant Science, 1-11.

Shahrajabian MH, W Sun and Q Cheng, 2019i. The power of natural Chinese medicine, ginger and ginseng root in an organic life. Middle East J. Sci. Res., 27: 64-71. 
Shojaii A, R Ghods and M Abdollahi Fard, 2016. Medicinal herbs in Iranian traditional medicine for learning and memory. Iran. J. Med. Sci., 41: S43.

Soleymani A, MM Shahri, MH Shahrajabian and L Naranjani, 2010. Responses of cultivars of canola to sulfur fertilizer and plant densities under climatic condition of Gorgan region, Iran. Journal of Food, Agriculture and Environment, 8: 298-304.

Soleymani A, MH Shahrajabian and L Naranjani, 2011a. The effect of plant density and nitrogen fertilization on yield, yield components and grain protein of grain sorghum. Journal of Food, Agriculture and Environment, 9: 244-246.

Soleymani A, MH Shahrajabian, SH Hosseini Far and L Naranjani, 2011b. Morphological traits, yield and yield components of safflower (Carthamus tinctorius L.) cultivars under drought stress condition in Kerman province. Journal of Food, Agriculture and Environment, 9: 249-251.

Soleymani A and MH Shahrajabian, 2012a. Response of different cultivars of fennel (Foeniculum vulgare) to irrigation and planting dates in Isfahan, Iran. Research on Crops, 13: 656-660.

Soleymani A and MH Shahrajabian, 2012b. The effects of Fe, Mn, and Zn foliar application on yield, ash and protein percentage of forage sorghum in climatic condition of Esfahan. Int. J. Biol., 4: 92-94.

Soleymani A, MH Shahrajabian and L Naranjani, 2013. Effect of planting dates and different levels of nitrogen on seed yield and yield components of nuts sunflower (Helianthus annuus L.). Afr. J. Agric. Res., 8: 58025805.

Soleymani A, MH Shahrajabian and M Khoshkharam, 2016. The impact of barley residue management and tillage on forage maize. Rom. Agric. Res., 33: 161-167.

Soleymani A and MH Shahrajabian, 2017. Effects of planting dates and row distance on sugar content, root yield and solar radiation absorption in sugar beet at different plant densities. Rom. Agric. Res., 34: 1-11.

Soleymani A and MH Shahrajabian, 2018. Changes in germination and seedling growth of different cultivars of cumin to drought stress. Cercetari Agronomice in Moldova, 1: 91-100.

Yong Y and MH Shahrajabian, 2017. Effects of intercropping and rotation on forage yield and quality of oat and common vetch in Jilin province, China. Research on Crop Ecophysiology, 12: 9-23.

Yong Y, Y Hu, MH Shahrajabian, C Ren, L Guo, C Wang and Z Zeng, 2018. Changes in dry matter, protein percentage and organic matter of soybean-oat and groundnut-oat intercropping in different growth stages in Jilin province, China. Acta Agriculturae Slovenica, 111: 1-7.

Zainalian M, M Eshaghi, H Naji, SMM Marandi, MR Sharbafchi and S Asgary, 2015. Iranian-Islamic traditional medicine: an ancient comprehensive personalized medicine. Adv. Biomed. Res., 4: 191.

Zeinalian M, M Eshaghi, M Hadian, H Naji, SMM Marandi and S Asgary, 2017. Eight essential foods in Iranian traditional medicine and their role in health promotion and well-being. Int. J. Prev. Med., 8:2. 